Revista Brasileira de Meteorologia, v.28, n.4, 364 - 372, 2013

\title{
TEMPORAL VARIABILITY OF EXTREME TEMPERATURE INDICES IN UTAH DURING THE PAST FEW DECADES
}

\author{
CARLOS ANTONIO COSTA DOS SANTOS, JOSÉ IVALDO BARBOSA DE BRITO, ELDER \\ GUEDES DOS SANTOS, TANTRAVAHI VENKATA RAMANA RAO, VICENTE DE PAULO \\ RODRIGUES DA SILVA
}

\author{
Universidade Federal de Campina Grande, Campina Grande, PB, Brasil \\ carlostorm@gmail.com, ivaldo@dca.ufcg.edu.br, elder.ufcg@gmail.com,ramanarao_tantravahi@yahoo. \\ com.br, vicente@dca.ufcg.edu.br \\ Received August 2011 - Accepted April 2013
}

\begin{abstract}
The main objective of this study was to analyze the trends in five annual extreme indices of temperature for Utah, USA. The analyses were conducted for 28 meteorological stations, during the period from 1970 to 2006, characterized by high quality data set. The analyses of extreme temperature indices have identified an increase in the maximum and minimum air temperatures in Utah. Predominantly, the minimum air temperature is increasing in the studied region. Most of Utah has shown a decrease in the diurnal temperature range, which indicates that the minimum temperature is increasing faster than the maximum temperature.
\end{abstract}

Keywords: Climate change, ETCCDMI, climatology, global warming, quality control.

\begin{abstract}
RESUMO: VARIABILIDADE TEMPORAL DOS ÍNDICES EXTREMOS DE TEMPERATURA EM UTAH DURANTE AS ÚLTIMAS DÉCADAS:

O principal objetivo desse estudo foi analisar as tendências de cinco índices anuais de extremos de temperatura para Utah, EUA. As análises foram feitas para 28 estações meteorológicas, durante o período de 1970 a 2006, sendo caracterizado como uma série de dados confiáveis. As análises dos índices extremos de temperatura identificaram um aumento nas temperaturas máximas e mínimas em Utah. As temperaturas mínimas estão aumentando, predominantemente, sobre a região estudada. A maior parte de Utah apresentou diminuição na amplitude térmica diária, que é um indicativo de que as temperaturas mínimas têm aumentado mais rápido do que as temperaturas máximas.
\end{abstract}

Palavras-chaves: Mudanças climáticas, ETCCDMI, climatologia, aquecimento global, controle de qualidade.

\section{INTRODUCTION}

There is no longer any scientific doubt that the Earth's average surface temperature is increasing and that changes in ocean temperature, ice and snow cover, and sea level are consistent with this global warming. In the past 100 years, the Earth's average surface temperature has increased by about $0.7^{\circ} \mathrm{C}$, with the rate of warming accelerating in recent decades (IPCC, 2007). Eleven of the last 12 years have been the warmest since 1850 (the start of reliable weather records). Cold days, cold nights, and frost have become less frequent, while heat waves have become more common. Mountain glaciers, seasonal snow cover, and the Greenland and Antarctic ice sheets are decreasing in size, global ocean temperatures have increased, and sea level has risen about 7 inches since 1900 and about 1 inch in the past decade (IPCC, 2007). Based on extensive scientific research, there is very high confidence that human generated increases in greenhouse gas concentrations are responsible for most of the global warming observed during the past 50 years.

In some regions temperature and precipitation extremes have already shown amplified responses to changes in mean values as shown by IPCC (2001). The effects of climatic change and variability have been investigated by many researchers throughout the world. The results of these studies have clearly 
shown that there is climate variability as a result of human interference on the ecosystems. Extreme climatic events, such as heat waves, floods and droughts, can have strong impact on society and ecosystems and are thus important to study (Moberg and Jones, 2005; Toreti and Desiato, 2008; Choi et al., 2009).

Studies aiming the investigation of changes in extreme climate events are important due to the potentially high social, economic and ecological impact of such events. In the past, the limited availability of long records of daily climate data in some parts of the world hampered efforts to analyze the impacts of climate change and variability on the frequency and severity of climate extremes around the globe (IPCC, 2001; Caesar et al., 2011). Thus, many studies have investigated climate change and extremes on different scales (Easterling et al., 2000; Vincent et al., 2005; Haylock et al., 2006; Brunetti et al., 2006; Santos and Brito, 2007; Santos et al., 2011). However, the Intergovernmental Panel on Climate Change (IPCC) in its reports (2001 and 2007) evidenced the need for more detailed information about regional patterns of climate change.

Many of the empirical studies on observed climate change have focused on mid to high-latitude locations where some of the most comprehensive datasets are available and where numerical models of climate predict the largest changes to occur given the buildup of greenhouse gases. Literally hundreds of studies from these locations revealed that over the past century, the average temperature has increased, the rate of increase accelerated in the most recent decades, the minimum daily temperature increased more quickly than the maximum temperature, and therefore, the diurnal temperature range generally decreased (Meehl et al. 2007, 2009; PeraltaHernandez et al. 2009).

In Utah, the average temperature during the past decade was higher than observed during any comparable period of the past century and roughly $1.1{ }^{\circ} \mathrm{C}$ higher than the 100 year average (NCDC, 2011). Declines in low-elevation mountain snowpack have been observed over the past several decades in the Pacific Northwest and California. However, clear and robust long-term snowpack trends have yet to emerge in Utah's mountains (Mote et al., 2005; Mote, 2006). Most of Utah's water resources originate in mountainous areas above $1800 \mathrm{~m}$ in elevation, which cover about $19 \%$ of the state. The primary source of this water is snowpack. Snow accumulates in these mountainous areas during winter and then melts in spring and early summer releasing months of stored precipitation in typically 4 to 8 weeks time.

Utah is projected to warm more than the average for the entire globe and more than coastal regions of the contiguous United States (Mote et al., 2005). The expected consequences of this warming are fewer frost days, longer growing seasons, and more heat waves. Studies of precipitation and runoff over the past several centuries and climate model projections for the next century indicate that ongoing greenhouse gas emissions at or above current levels will likely result in a decline in Utah's mountain snowpack and the threat of severe and prolonged episodic drought in Utah is real (UDWR, 2007; Abatzoglou, 2011). Preparation for the future impacts of climate variability and change on Utah requires enhanced monitoring and knowledge of Utah's climate, as well as better understanding of the impacts of weather and climate on the state's water availability, agriculture, industry, and natural resources.

It is known that tourism and outdoor recreation have been an important, growing sector of Utah's economy. During the winter months, the ski and snow sport industry provides the main activities. Changes in temperature patterns could have significant impacts on season lengths and the quality of the snow in the future, affecting the economic viability of this industry. Thus, trends in regional temperature extremes and their indication of climate change are of interest to Utah. The trends obtained herein corroborate the general idea that during the last decades the globe has warmed.

This study is aimed to provide an overview on the spatial and temporal variations of temperature extremes under the rapid warming during the past few decades over Utah, USA, through the analysis of different indices based on observational data from multiple stations in the region.

\section{MATERIAL AND METHODS}

\subsection{Data and quality control}

Daily maximum and minimum surface air temperatures data were taken from 28 meteorological stations across Utah, USA, between $37-41^{\circ} \mathrm{N}$ latitude and $109-114^{\circ} \mathrm{W}$ longitude and for the period between $1970-2006$. This period has been chosen because it characterizes a climatological dataset for each station. The map of station locations is shown in Figure 1 ; the numbers indicating the stations with their names and coordinates shown in Table 1. The dataset was provided by National Climatic Data Center.

The dataset was processed using the freely available software packages: RClimDex, which performs data quality control and calculates indices, and RHtest, which performs homogeneity tests. These packages were downloaded from the ETCCDI website (http://cccma.seos.uvic.ca/ETCCDI/). An updated version of RClimDex that takes account of the precision of the input data (Zhang et al., 2005) has been used. The homogeneity test has been done using the RHtest software package, which can help to identify step changes in a time series by comparing the goodness of fit of a two-phase regression model with that of a linear trend for the entire series (Wang, 
Table 1 - Meteorological stations used for the analysis of maximum and minimum daily air temperature in Utah, USA.

\begin{tabular}{clccc}
\hline ID & \multicolumn{1}{c}{ STATION } & LAT (N) & LON (W) & ELEVATION (m) \\
\hline 1 & Bryce Canyon & 37.633 & -112.183 & 2412 \\
2 & Alton & 37.440 & -112.482 & 2146 \\
3 & Blanding & 37.613 & -109.485 & 1855 \\
4 & Laketown & 41.825 & -111.321 & 1823 \\
5 & Escalante & 37.769 & -111.598 & 1771 \\
6 & Manti & 39.258 & -111.631 & 1750 \\
7 & Castle Dale & 39.174 & -111.029 & 1713 \\
8 & Cedar City & 37.709 & -113.094 & 1703 \\
9 & Heber & 40.491 & -111.426 & 1716 \\
10 & Duchesne & 40.168 & -110.395 & 1682 \\
11 & Levan & 39.554 & -111.867 & 1612 \\
12 & Fillmore & 38.966 & -112.328 & 1561 \\
13 & Morgan Power \& Light & 41.043 & -111.672 & 1551 \\
14 & Canyonlands & 38.150 & -109.782 & 1523 \\
15 & Kanab & 37.027 & -112.537 & 1506 \\
16 & Black Rock & 38.708 & -112.953 & 1492 \\
17 & Tooele & 40.527 & -112.298 & 1545 \\
18 & Logan & 41.745 & -111.803 & 1460 \\
19 & Jensen & 40.364 & -109.345 & 1448 \\
20 & Spanish Fork & 40.079 & -111.604 & 1439 \\
21 & Deseret & 39.267 & -112.652 & 1399 \\
22 & Hanksville & 38.371 & -110.715 & 1313 \\
23 & Ogden & 41.244 & -111.946 & 1326 \\
24 & Callao & 39.899 & -113.713 & 1320 \\
25 & Mexican Hat & 37.149 & -109.868 & 1254 \\
26 & Salt Lake City & 40.778 & -111.969 & 1288 \\
27 & Zion's National Park & 37.208 & -112.984 & 1234 \\
28 & Moab & 38.574 & -109.546 & 1241 \\
\hline
\end{tabular}
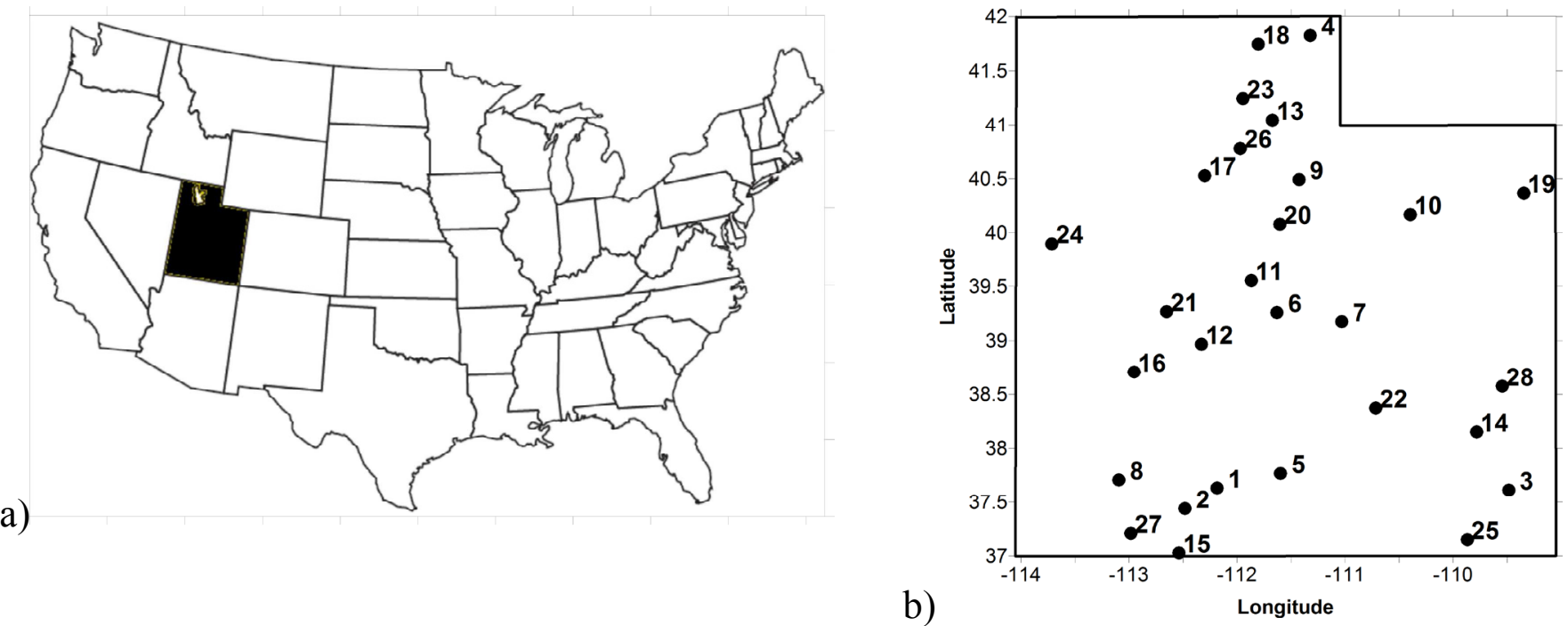

Figure 1 - (a) Map of the USA with the state of Utah highlighted; and (b) map of Utah with the locations of the stations used in this study. The numbers relate to the name, latitude, longitude and elevation of the selected stations presented in Table 1 . The time series used for these stations was from 1970 to 2006 . 
2008; Caesar et al., 2011). RHtest is used to help identify series break points for further investigation. Reeves et al. (2007) found that two-phase regression methods, as implemented in the RHtest software, had a comparable level of performance to methods such as the standard normal homogeneity test, with the optimal choice depending on the priorities of the user (e.g. accurately detecting the date of a changepoint or minimizing the number of false alarms). They also found that developments in the two-phase regression method since 1995, reflected in recent versions of RHtest, had substantially improved its performance (Caesar et al., 2011).

An exhaustive data quality control was conducted because indices of extremes are sensitive to changes in station location, exposure, equipment, and observer practice (Haylock et al., 2006). Data Quality Control (QC) is a prerequisite for determining climatic indices. The quality control module of the RClimdex software performs the following procedures: 1) Replaces all missing values (currently coded as -99.9) into an internal format that the software recognizes (i.e. NA, not available), and 2) Replaces all unreasonable values into NA. Those values include daily maximum temperature less than daily minimum temperature. In addition, the QC also identified outliers in daily maximum and minimum temperature. The outliers are daily values outside a range defined by the user. Currently, this range is defined as $n$ times standard deviation $(s d t)$ of the value for the day, that is, (mean $-n \times s t d$, mean + $n \times s t d$ ), where $s t d$ for the day and $n$ is an input from the user (Zhang and Yang, 2004; Vincent et al., 2005). Initially, data from 40 meteorological stations were available, and after the QC, only stations with less than $10 \%$ of missing data for a period of at least 37 years were considered, resulting in the 28 stations used in the analyses (Table 1).

\subsection{Methodology}

The RClimdex software developed by Xuebin Zhang and Feng Yang from Canadian Meteorological Service (Zhang and Yang, 2004) was used in this study to obtain the climatic extremes indices, following methodologies of Haylock et al. (2006). A set of 10 indices to indicate the trend and significance of extreme temperature events was used for this study. They were adopted from the list of extreme indices proposed by the ETCCDMI (http:// cccma.seos.uvic.ca/ETCCDI/indices.shtml) and they better explain the temperature behavior of Utah (Moller and Gillies, 2008). The 10 extreme temperature indices are briefly described in Table 2 .

Linear trend analyses were performed for all temperature indices used in the study. The slopes of the linear trends are calculated by least squares fitting. Since a normal frequency distribution may not necessarily fit very well to indices data, a non-parametric Mann-Kendall test (Sneyers, 1990) is used to identify whether or not trends are significant. The method is simple and robust, and it also has the advantage of being able to deal with missing values.

The null hypothesis $\left(H_{0}\right)$ states that the deseasonalized data $\left(x_{1}, x_{2}, \ldots, x_{n}\right)$ is a sample of $n$ independent and identically distributed random variables. The null hypothesis that standard normal variable $\left(Z_{c}\right)$ is not statistically significant or has no significant trend is accepted if $-Z_{1-p / 2} \leq Z_{c} \leq Z_{1-p / 2}$, where $Z_{1-p / 2}$ is the standard normal deviate and $p$ is the significance level for the test. Or, $Z_{c}$ is statistically significant if $Z_{c}<-Z_{1-p / 2}$ or if $Z_{c}>Z_{1-p / 2}$ (Partal and Kahya, 2006). Kendall's statistic $(S)$ is computed as follows:

$$
S=\sum_{k=1}^{n-1} \sum_{j=k+1}^{n} \operatorname{sgn}\left(x_{j}-x_{k}\right)
$$

The variance of $S$ is given by

$$
\operatorname{var}(S)=\frac{n(n-1)(2 n+5)-\sum_{i=1}^{m} e_{i}\left(e_{i}-1\right)\left(2 e_{i}+5\right)}{18}
$$

where, $x_{j}, x_{k}$ are sequential data values; $n$ is the length of the dataset; $m$ is the number of tied groups; and $e_{i}$ is the size of the $i$ th tied group. $Z_{c}$ is obtained as follows:

Table 2 - Definition of extreme air temperature indices used in this study.

\begin{tabular}{cllc}
\hline Indices & \multicolumn{1}{c}{ Name } & \multicolumn{1}{c}{ Definition } & Units \\
\hline $\mathrm{HD}$ & Hottest day & Highest maximum temperature in a year & ${ }^{\circ} \mathrm{C}$ \\
$\mathrm{HN}$ & Hottest night & Highest minimum temperature in a year & ${ }^{\circ} \mathrm{C}$ \\
$\mathrm{CD}$ & Coldest day & Lowest maximum temperature in a year & ${ }^{\circ} \mathrm{C}$ \\
$\mathrm{CN}$ & Coldest night & Lowest minimum temperature in a year & ${ }^{\circ} \mathrm{C}$ \\
DTR & Diurnal Temperature Range & Annual mean of difference between maximum & ${ }^{\circ} \mathrm{C}$ \\
& & temperature and minimum temperature &
\end{tabular}




$$
\begin{array}{ll}
Z_{c}=\frac{S-1}{\sqrt{\operatorname{var}(S)}} \quad(\mathrm{S}>0) \\
Z_{c}=0 \quad(\mathrm{~S}=0) \\
Z_{c}=\frac{S+1}{\sqrt{\operatorname{var}(S)}} \quad(\mathrm{S}<0)
\end{array}
$$

Positive values of $Z_{c}$ indicate increasing trends while negative $Z_{c}$ shows decreasing trends. When testing either increasing or decreasing monotonic trends at a significance level $p$, the null hypothesis was rejected for absolute value of $Z_{c}$ greater than $Z_{1-p / 2}$ (Partal and Kahya, 2006). In this study, significance level $p$ of 0.05 is applied.

The spatial distribution of the indices trends was represented using the symbols $(\mathbf{+})$ for positive trends, and $(\bullet)$ for negative trends, statistically significant at $95 \%$ level, i.e. $p<0.05$. The representation of the trends which are statistically non-significant at the $95 \%$ level used the symbols (+) for positive trends, and (o) for negative trends.

\section{RESULTS AND DISCUSSIONS}

Table 3 shows the annual trends of five extreme indices of air temperature in Utah for 28 stations. The bold and highlighted values represent significant level of 5\% $(p<0.05)$. The discussions presented in this study are only for those trends that showed significant level of 5\%. The hottest day index (HD), presented 9 stations with positive trends and 2 stations with negative trends, showing a predominant increase in the highest maximum temperature in a year in this area (Figure 2a). The coldest day index (CD) shows a similar behavior, with only positive trends (12 stations), showing that the lowest maximum temperature in a year is increasing as

\begin{tabular}{|c|c|c|c|c|c|c|}
\hline STATION & ELEV. (m) & HD & HN & CD & $\mathbf{C N}$ & DTR \\
\hline Bryce Canyon & 2440 & -0.006 & -0.001 & 0.001 & 0.152 & -0.067 \\
\hline Alton & 2181 & 0.030 & 0.075 & 0.031 & 0.107 & -0.006 \\
\hline Blanding & 1841 & 0.086 & 0.160 & 0.065 & 0.227 & -0.029 \\
\hline Laketown & 1823 & -0.002 & 0.101 & 0.062 & 0.137 & -0.057 \\
\hline Escalante & 1757 & 0.062 & 0.159 & 0.041 & 0.130 & 0.016 \\
\hline Manti & 1732 & 0.019 & 0.061 & 0.042 & 0.173 & -0.029 \\
\hline Castle Dale & 1725 & 0.029 & 0.140 & 0.007 & 0.150 & 0.047 \\
\hline Cedar City & 1713 & -0.007 & 0.046 & 0.003 & 0.000 & 0.037 \\
\hline Heber & 1704 & 0.069 & 0.188 & 0.036 & 0.262 & 0.000 \\
\hline Duchesne & 1684 & -0.039 & 0.178 & -0.001 & 0.246 & -0.047 \\
\hline Levan & 1616 & 0.050 & 0.140 & 0.005 & 0.161 & -0.005 \\
\hline Fillmore & 1556 & -0.068 & 0.038 & -0.037 & 0.263 & -0.083 \\
\hline Morgan Power & 1546 & 0.083 & 0.185 & 0.094 & 0.290 & -0.022 \\
\hline Canyonlands & 1537 & 0.037 & 0.080 & 0.048 & 0.125 & -0.037 \\
\hline Kanab & 1528 & 0.023 & 0.032 & 0.044 & 0.097 & -0.012 \\
\hline Black Rock & 1482 & -0.013 & 0.092 & 0.025 & 0.129 & -0.009 \\
\hline Toole & 1470 & 0.122 & 0.166 & 0.064 & 0.143 & 0.049 \\
\hline Logan & 1458 & 0.052 & 0.221 & 0.021 & 0.167 & 0.003 \\
\hline Jehsen & 1446 & 0.059 & 0.216 & 0.050 & 0.200 & 0.011 \\
\hline Spanish Fork & 1437 & 0.024 & 0.139 & 0.034 & 0.132 & -0.010 \\
\hline Deseret & 1384 & -0.004 & 0.145 & 0.017 & 0.149 & 0.007 \\
\hline Hanksville & 1360 & 0.035 & 0.100 & 0.095 & 0.202 & -0.027 \\
\hline Ogden & 1327 & 0.027 & 0.172 & 0.024 & 0.207 & -0.026 \\
\hline Callao & 1324 & 0.083 & 0.167 & 0.084 & 0.138 & 0.038 \\
\hline Mexican Hat & 1296 & 0.014 & 0.201 & 0.072 & 0.102 & -0.006 \\
\hline Salt Lake City & 1296 & 0.020 & 0.093 & 0.071 & 0.112 & -0.033 \\
\hline Zion National Park & 1235 & 0.057 & 0.067 & -0.005 & 0.111 & 0.043 \\
\hline Moab & 1220 & 0.041 & 0.143 & 0.031 & 0.182 & 0.021 \\
\hline
\end{tabular}

Table 3 - Annual trends of the extreme indices of air temperature for Utah, USA. The bold and highlighted values represent significance at $5 \%$ level $(\mathrm{p} \leq 0.05)$. 
well. The spatial distribution is shown in Figure 2b, and these results indicate an increase in the maximum temperature in the studied area. The highest minimum temperature in a year, i.e. hottest night index $(\mathrm{HN})$, shows only positive trends (Figure $2 \mathrm{c})$. The coldest night $(\mathrm{CN})$ index presented a similar behavior with only positive trends ( 9 stations), indicating that the lowest minimum temperature in a year is also increasing in this region (Figure 2d).

These results are in agreement with those found by Meehl et al. (2007) and show an unfavorable situation because the water

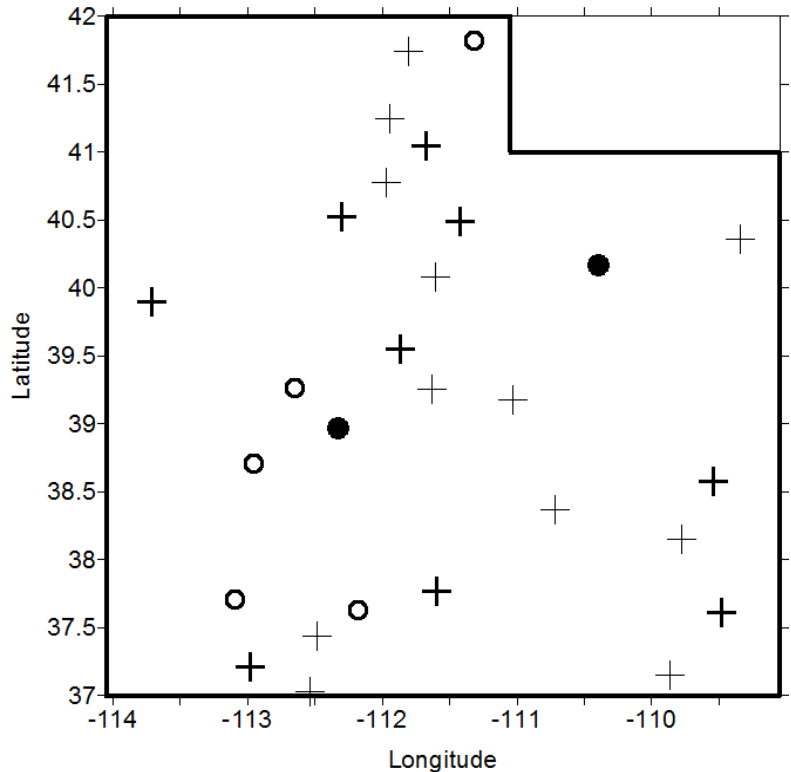

a)

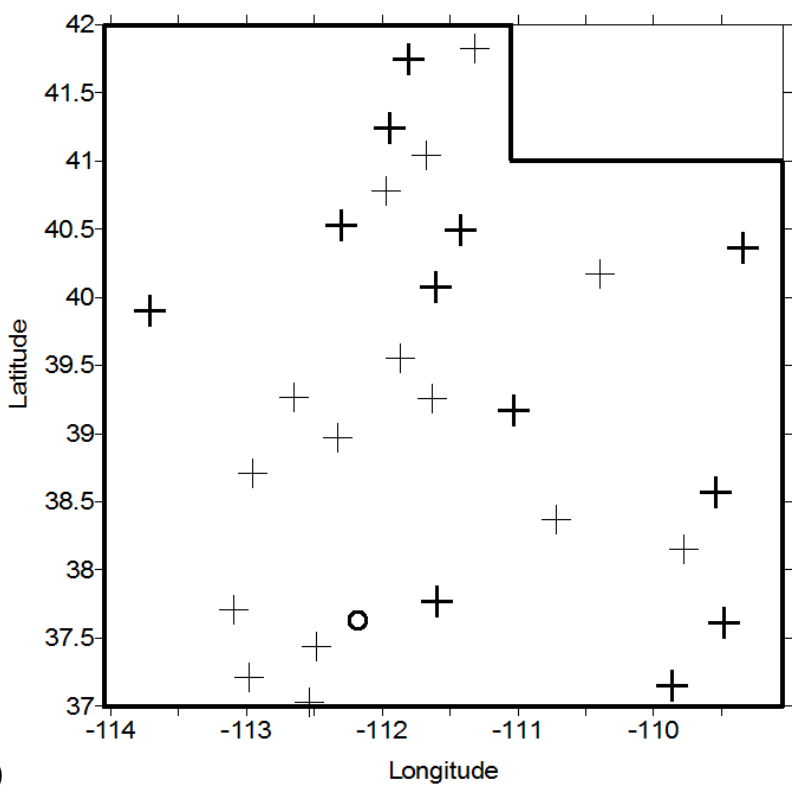

to human consumption and agriculture in Utah is provided by the snow on the mountains and with the air minimum temperature increasing the melting will be accelerated hindering the water management in the State (Mote et al., 2005; Mote, 2006; Abatzoglou, 2011). The increase of the air temperature in the study area was also previously identified by Karl et al. (1996) and Meehl et al. (2007; 2009). Additionally, diurnal temperature range (DTR) index shows negative trends at 10 stations and positive trends at 4 stations (Figure 3), indicating that the annual mean of difference between maximum temperature and

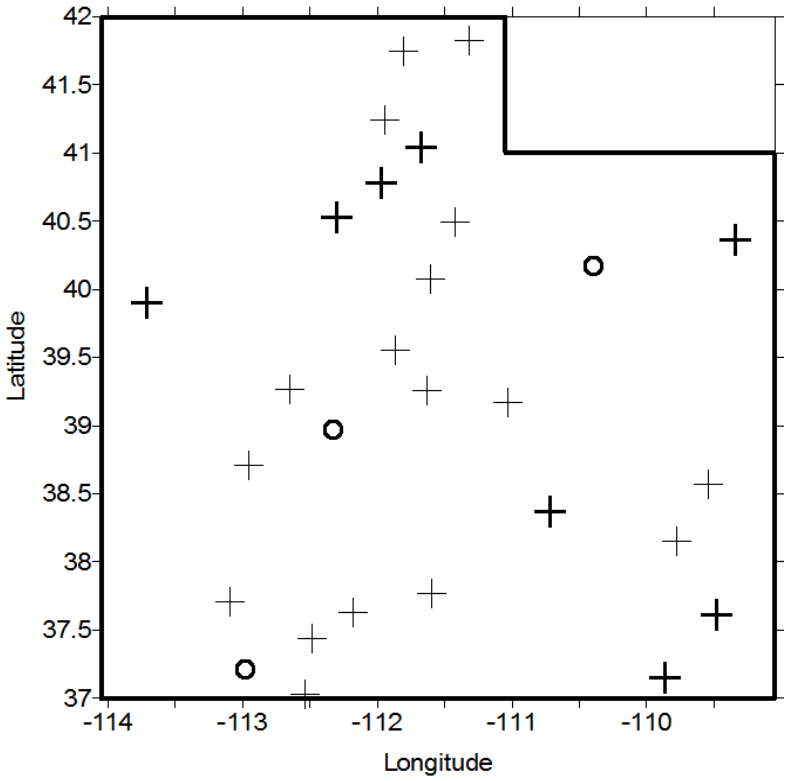

b)

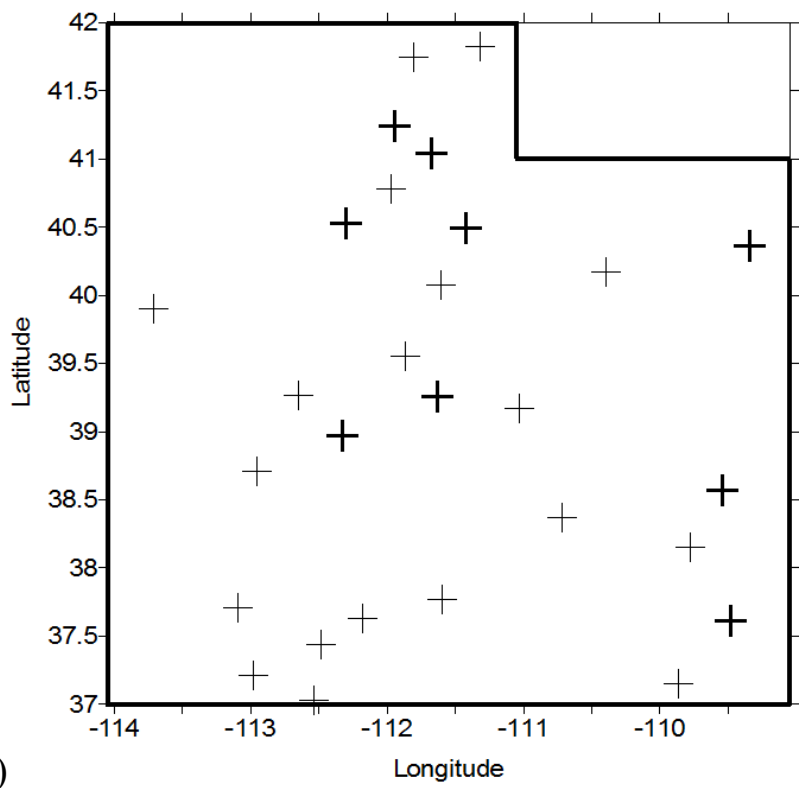

Figure 2 - Spatial distribution of temperature extreme trends for Utah, USA. The symbol (\$) means positive trends, and $(\bullet)$ means negative trends, statistically significant at $95 \%$ level $(\mathrm{p}<0.05)$, while the symbols $(+)$ means positive trends, and $(\mathrm{o})$ means negative trends statistically non-significant. (a) HD index, (b) HN index, (c) CD index and (d) $\mathrm{CN}$ index. 
minimum temperature is decreasing in the studied area. These results are in agreement with the results obtained for $\mathrm{HD}, \mathrm{HN}$, $\mathrm{CD}$ and $\mathrm{CN}$ indices and are similar to the results obtained by Alexander et al. (2006).

To assist with the interpretation of figures that involve analyses of temperature extremes indices, the percentage of stations with statistically significant and insignificant trends at the $5 \%$ level were calculated and are shown in Table 4 . It can be observed that $32.1 \%$ of the stations show a significant increase in HD, $42.8 \%$ in $\mathrm{CD}, 28.6 \%$ in $\mathrm{HN}$ and $32.1 \%$ in $\mathrm{CN}$, indicating an increase of temperature. While there is a significant decrease of $35.7 \%$ in DTR, indicating a decrease in this index consistent with the results previously shown and IPCC (2007).

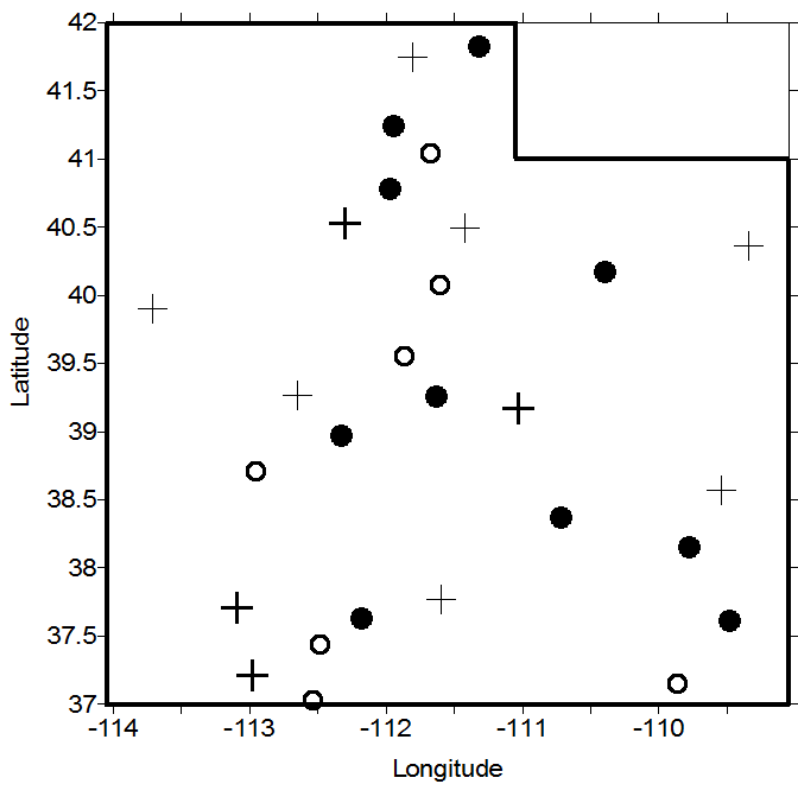

Figure 3 - Spatial distribution of Diurnal Temperature Range (DTR) trends for Utah, USA. The symbol (\$) means positive trends, and (•) means negative trends, statistically significant at $95 \%$ level $(\mathrm{p}<0.05)$, while the symbols $(+)$ means positive trends, and $(\mathrm{o})$ means negative trends statistically non-significant.
IPCC (2007) affirms that the temperatures across western North America have seen a pronounced warming over the past 50 years. Warming temperatures may lead to ecological and economic impacts with respect to the timing of hydrologic processes across much of the western United States including an advance in the timing of snowmelt runoff and blooming of plants (Abatzoglou and Redmond, 2007).

Utah has the agriculture as an important economic activity accounting about $14 \%$ of the total when considered with the associated processing sector. In Utah, the irrigated agriculture is dependent on winter snowpack accumulation and storage as the main water supply for the summer months. Some important effects of an increase in temperature, especially in regions where agricultural production is seasonally limited by temperature as in Utah, can be the extension of the growing season, increase soil evaporation rates and severe droughts (Linderholm, 2006). As well as, tourism and outdoor recreation has been an important, growing sector of Utah's economy. During the winter months, the ski and snow sport industry provides the main activities. Thus, changes in temperature patterns could have significant impacts on season's length and the quality of the snow in the future, affecting the economic viability of this industry.

The trends obtained herein corroborate the general idea that during the last century the globe has warmed. Meehl et al. (2007) affirms that the natural forcings, including only solar and volcanoes, show little change in the extremes indices for the latter part of the 20th century over U.S. This indicates that the recent observed changes in temperature extremes over the U.S. have been mostly due to changes in anthropogenic forcing associated with increases of greenhouse gases. Additionally, the experience acquired with this study for Utah, USA, can be extended to other regions. Future research should incorporate more regional stations in surrounding states, possibly stratifying the analysis by elevation and regional microclimates with a closer look to weather station location and possible urbanization effects.

Table 4 - The percentage of stations showing significant and not significant trends at the $5 \%$ level for the temperature indices for Utah, USA.

\begin{tabular}{ccccc}
\hline INDICE & $\begin{array}{c}\text { Positive significant } \\
\text { trend } \\
(\%)\end{array}$ & $\begin{array}{c}\text { Positive not significant } \\
\text { trend } \\
(\%)\end{array}$ & $\begin{array}{c}\text { Negative significant } \\
\text { trend } \\
(\%)\end{array}$ & $\begin{array}{c}\text { Negative not significant } \\
\text { trend } \\
(\%)\end{array}$ \\
\hline HD & 32.1 & 42.8 & 7.1 & 18.0 \\
HN & 42.8 & 53.6 & 0.0 & 3.6 \\
CD & 28.6 & 60.7 & 0.0 & 10.7 \\
CN & 32.1 & 67.9 & 0.0 & 0.0 \\
DTR & 14.3 & 25.0 & 35.7 & 25.0 \\
\hline
\end{tabular}




\section{CONCLUSIONS}

Studies have shown that one of the most important questions regarding extreme events is if their occurrence is increasing or decreasing over time, characterized by the frequency of these events and if they are changing significantly. This study presents temporal analyses of the trends in five annual extreme indices of air temperature for Utah, USA. The analyses were conducted using high quality data sets for 28 meteorological stations for a period between 1970 and 2006.

A predominant increase in the annual temperature indices has been found in the study region. Most of Utah has shown that the difference between maximum and minimum temperatures is decreasing, indicating that the minimum temperature is increasing faster than the maximum temperature.

The analysis has identified that the temperature has increased in Utah during the last three decades. The evaluation of the extreme temperature indices and their trends may help to a better understanding of the possible regional and local scale impacts of climate change on agriculture and human health.

\section{REFERENCES}

ABATZOGLOU, J. T. Influence of the PNA on declining mountain snowpack in the Western United States. International Journal of Climatology, v. 31, p. 1135 1142, 2011.

ABATZOGLOU, J. T., REDMOND, K. T. Asymmetry between trends in spring and autumn temperature and circulation regimes over western North America. Geophysical Research Letters, v. 34, L18808, 2007.

ALEXANDER, L. V., et al. Global observed changes in daily climate extremes of temperature and precipitation. Journal of Geophysical Resources, v. 111, D05109, 2006.

BRUNETTI, M., MAUGERI, M., MONTI, F., NANNI, T. Temperature and precipitation variability in Italy in the last two centuries from homogenized instrumental time series. International Journal of Climatology, v. 26, p. 345-381, 2006.

CAESAR, J. et al. Changes in temperature and precipitation extremes over the Indo-Pacific region from 1971 to 2005. International Journal of Climatology, v. 31, p. 791-801, 2011.

CHOI, G., COLLINS, D., REN, G., TREWIN, B., BALDI, M., FUKUDA, Y., AFZAAL, M., PIANMANA, T., GOMBOLUUDEV, P., HUONG, P. T. T., LIAS, N., KWON, W. T., BOO, K. O., CHAA, Y. M., ZHOUC, Y. Changes in means and extreme events of temperature and precipitation in the Asia-Pacific Network region, 1955-2007. International Journal of Climatology, v. 29, p. 1906-1925, 2009.
EASTERLING, D. R., EVANS, J. L., GROISMAN, P. Y., KARL, T. R., KUNKEL, K. E., AMBENJE, P. Observed variability and trends in extreme climate events. Bulletin of American Meteorological Society, v. 81, p. 417-425, 2000.

HAYLOCK, M. R. et al. Trends in total and extreme South American rainfall 1960-2000 and links with sea surface temperature. Journal of Climate, v. 19, p. 1490-1512, 2006.

IPCC. 2001. Climate Change 2001: Impacts, Adaptation, and Vulnerability. Contribution of Working Group II to the Third Assessment Report of the Intergovernmental Panel on Climate Change. Cambridge University Press: Cambridge, New York.

IPCC. 2007. Climate Change 2007 - The Physical Science Basis. Contribution of Working Group I to the Fourth Assessment Report of the IPCC. Cambridge Univ. Press, Cambridge.

KARL, T. R., KNIGHT, R. W., EASTERLING, D. R., QUAYLE, R. G. Indices of climate change for the United States. Bulletin of the American Meteorological Society, v. 77, p. 279-292, 1996.

LINDERHOLM, H. W. Growing season changes in the last century. Agricultural and Forest Meteorology, v. 137, p. $1-14,2006$.

MEEHL, G. A., ARBlaster, J. M., TEBAldi, C. Contributions of natural and anthropogenic forcing to changes in temperature extremes over the U.S. Geophysical Research Letters, v. 34, p. L19709, 2007.

MEEHL, G. A., TEBALDI, C., WALTON, G., EASTERLING, D., MCDANIEL, L. Relative increase of record high maximum temperatures compared to record low minimum temperatures in the U.S. Geophysical Research Letters, v. 36, p. L23701, 2009.

MOBERG, A., JONES, P. D. Trends in indices for extremes in daily temperature and precipitation in Central and Western Europe, 1901-99. International Journal of Climatology, v. 25, p. 1149-1171, 2005.

MOLLER, A. L., GILlIES, R. R. Utah Climate. Publication Design and Production: Utah State University, Logan-UT/ USA, second Edition, 2008.

MOTE, P. W. Climate-Driven Variability and Trends in Mountain Snowpack in Western North America. Journal of Climate, v. 19, p. $6209-6220,2006$.

MOTE, P. W., HAMLET, A. F., CLARK, M. P., LETTENMAIER, D. P. Declining mountain snowpack in Western North America. Bulletin of the American Meteorological Society, v. 86, p. $39-49,2005$.

NCDC - National Climate Data Center, http://www.ncdc.noaa. gov/oa/ncdc.html. Accessed in 29/08/ 2011.

PARTAL, T., KAHYA, E. Trend analysis in Turkish precipitation data. Hydrological Processes, v. 20, p. 2011-2026, 2006. 
PERALTA-HERNANDEZ, A. R., BALLING, JR., R. C., BARBA-MARTINEZA, L. R. Analysis of near-surface diurnal temperature variations and trends in southern Mexico. International Journal of Climatology, v. 29, p. $205-209,2009$.

REEVES, J., CHEN, J., WANG, X. L., LUND, R., LU, Q. A review and comparison of changepoint detection techniques for climate data. Journal of Applied Meteorology and Climatology, v. 46, p. 900-915, 2007.

SANTOS, C. A. C., BRITO, J. I. B. Análise dos índices de extremos para o semi-árido do Brasil e suas relações com TSM e IVDN. Revista Brasileira de Meteorologia, v. 22, p. 303-312, 2007.

SANTOS, C. A. C., NEALE, C. M. U., RAO, T. V. R., SILVA, B. B. Trends in indices for extremes in daily temperature and precipitation over Utah, USA. International Journal of Climatology, 2011, DOI: 10.1002/joc.2205.

SNEYERS R. On the Statistical Analysis of Series of Observations. Technical Note No. 143, WMO No. 415 World Meteorological Organization: Geneva. 1990.
TORETI, A., DESIATO, F. Changes in temperature extremes over Italy in the last 44 years. International Journal of Climatology, v. 28, p. 733-745, 2008.

UDWR - Utah Division of Wildlife Resources, http://wildlife. utah.gov/dwr/. Accessed in 09/08/ 2011.

VINCENT, L. A. et al. Observed trends in indices of daily temperature extremes in South America 1960-2000. Journal of Climate, v. 18, p. 5011-5023, 2005.

WANG, X. L. L. Penalized maximal $F$ test for detecting undocumented mean shift without trend change. Journal of Atmospheric and Oceanic Technology, v. 25: 368-384, 2008.

ZHANG, X. et al. Trends in Middle East climate extremes indices during 1930-2003. Journal of Geophysical Research, v. 110, p. D22104, 2005.

ZHANG, X., YANG, F. RClimDex (1.0) User Guide. Climate Research Branch Environment Canada. Downsview (Ontario, Canada), 2004. 